\title{
Kinetic and thermodynamic control of axial chirality in biaryl-derived fused oxazolidine lactams exploiting a centre-axis relay of unit efficiency
}

\author{
David J. Edwards, ${ }^{a}$ David House, ${ }^{b}$ Helen M. Sheldrake, ${ }^{a}$ Susan J. Stone ${ }^{a}$ and Timothy W. Wallace*a
}

\author{
Received 27th April 2007, Accepted 18th June 2007 \\ First published as an Advance Article on the web 3rd July 2007 \\ DOI: 10.1039/b706336a
}

The condensation of a 2-substituted-2-aminoethanol with methyl 2'-formylbiphenyl-2-carboxylate produces only two of the four possible axially chiral 6,7-dihydrodibenz[c,e]oxazolo[3,2-a]azepin9(4b $H$ )-ones (fused oxazolidine lactams), with kinetically controlled diastereoisomer ratios of up to 96 :

4. Within each lactam product the central chirality of the oxazolidine-fused benzylic position $\mathrm{C}(4 \mathrm{~b})$ is relayed to the biaryl axis with unit efficiency, the mis-matching of these stereogenic elements being prohibited due to strain, as predicted by molecular mechanics calculations. Diastereoisomeric lactam pairs can be equilibrated by heating with acid, and under these thermodynamic conditions reversed diastereoisomer ratios of up to $26: 74$ are observed.

\section{Introduction}

The control of axial chirality in biaryls has been a focus of much attention in recent years as these materials became prominent in synthetic, materials and supramolecular chemistry, and prompted the development of new methods for their enantioselective (atroposelective) synthesis. ${ }^{1}$ The key component of chiral biaryls, a stereogenic axis, is also biologically significant, there being a large number of compounds whose physiological properties depend on their axial configuration. These include not only fixed-axis biaryls such as $(\mathrm{a} R)$-gossypol, an oral anti-spermatogenic agent, ${ }^{2}$ but also many flexible systems exemplified by $N$-acetylcolchinol methyl ether (NCME) 1, an antimitotic agent whose (a $R$ )-form binds strongly to tubulin ${ }^{3}$ and whose $(\mathrm{a} R)$ - and $(\mathrm{a} S)$-forms equilibrate in solution (ratio $3: 1$ in chloroform- $d$ ). ${ }^{4}$ These properties of 1 serve to illustrate the phenomenon of dynamic axial chirality which, in appropriate circumstances, can be manipulated (e.g. inverted) to useful effect without breaking bonds. ${ }^{5}$ The sense of the axial chirality in NCME 1 depends on the configuration of the benzylic stereocentre, where the acetamido substituent prefers a pseudo-equatorial orientation, and the three-atom bridge effectively operates as a mechanical centre-axis chirality relay. The degree of axial chirality in biaryls, i.e. the aryl-aryl dihedral angle, can also be controlled using suitable designs of multi-atom bridge. ${ }^{6,7}$

The interplay between benzylic central chirality and axis configuration, as illustrated above, is a recurrent theme in atroposelective biaryl synthesis, ${ }^{1}$ and our interest in this area led us to investigate the potential of [7,5]-fused lactams based on 6,7dihydrodibenz[c,e]oxazolo[3,2- $a$ ]azepin-9-one $\mathbf{2}$ as conformationally restrained biaryls. Although the ring system in $\mathbf{2}$ is analogous to the [5,5]- and [6,5]-fused lactams introduced and exploited so productively by Meyers and co-workers, ${ }^{8}$ the biaryl lactams described in our preliminary publication ${ }^{9}$ were the first of their

${ }^{a}$ School of Chemistry, The University of Manchester, Oxford Road, Manchester, M139PL, UK.E-mail: tim.wallace@manchester.ac.uk; Fax: +44 (0) 1612754939

${ }^{b}$ Synthetic Chemistry, GlaxoSmithKline, Medicines Research Centre, Gunnels Wood Road, Stevenage, SG1 2NY, UK


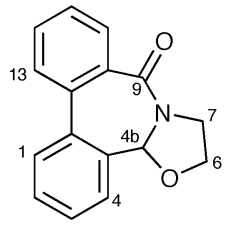

2

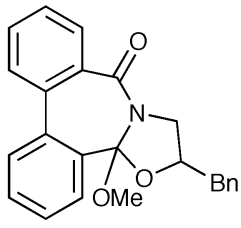

3<smiles>O=C1COC2c3ccccc3-c3ccccc3CN12</smiles>

4 type. However, the heterocyclic nucleus was already known in the form of $3^{10}$ and $4,{ }^{11}$ and another series of lactams based on 2 was subsequently described by Levacher and co-workers. ${ }^{12,13}$ We report herein the details of our initial study, in which we identify complementary kinetic and thermodynamic routes to biaryl lactams of the form $\mathbf{2}$, and from which we conclude that a chirality relay of unit efficiency links the biaryl axis and C(4b) in such systems.

\section{Results and discussion}

The starting materials for our study were prepared from commercial diphenic anhydride $\mathbf{5}$ using the two sequences shown in Scheme 1 . Heating the anhydride $\mathbf{5}$ with hydrazine hydrate gave the hydrazide $6,{ }^{14}$ which could be cleaved to the acid-aldehyde 7 using periodic acid; ${ }^{15}$ the ozonolysis of phenanthrene offers an alternative route to $7 .{ }^{16}$ The corresponding ester 9 was prepared by opening the anhydride 5 with methanol, followed by reduction to the known ester-alcohol 8 using borane-methyl sulfide. ${ }^{17}$ The oxidation of $\mathbf{8}$ to 9 with manganese(Iv) oxide has been described, ${ }^{18}$ but in our hands this reaction sometimes gave significant amounts 
<smiles>O=c1oc(=O)c2ccccc2c2ccccc12</smiles>

5

$\mathrm{MeOH}$, heat $0{ }^{\circ} \mathrm{C}$ to RT, $24 \mathrm{~h}(67 \%)$<smiles>CC(=O)c1ccccc1-c1ccccc1CO</smiles>

8 then $\mathrm{BH}_{3} \cdot \mathrm{SMe}_{2}$, THF $-78{ }^{\circ} \mathrm{C}, 0.5 \mathrm{~h}$ then $\mathrm{Et}_{3} \mathrm{~N}(91 \%)$<smiles>COC(=O)c1ccccc1-c1ccccc1C=O</smiles>

9<smiles>NNC(=O)c1ccccc1-c1ccccc1C(=O)O</smiles>

6

$\mathrm{NH}_{4} \mathrm{OH}, \mathrm{H}_{5} \mathrm{IO}_{6}, \mathrm{H}_{2} \mathrm{O}$ $0{ }^{\circ} \mathrm{C}$ to $\mathrm{RT}$ then $\mathrm{H}_{2} \mathrm{SO}_{4}(50 \%)$<smiles>O=Cc1ccccc1-c1ccccc1C(=O)O</smiles>

7<smiles>O=C1OCc2ccccc2-c2ccccc21</smiles>

10
Scheme 1 Preparation of biaryl starting materials $\mathbf{7}$ and $\mathbf{9}$.

of the lactone 10, a result which we ascribe to the variable activity of the manganese reagent. Fortunately the oxidation of $\mathbf{8}$ under Swern conditions ${ }^{19}$ afforded the ester-aldehyde 9 cleanly and in good yield.

The polycyclic nucleus of $\mathbf{2}$ was first assembled by heating the acid-aldehyde 7 with $(S)$-valinol 11a under dehydrating conditions, which gave a mixture of two products as indicated by ${ }^{1} \mathrm{H}$ NMR spectroscopy and TLC (Scheme 2 and Table 1). The characterising features of the NMR spectrum of the mixture were two singlets at $\delta 5.91$ and $5.73 \mathrm{ppm}$, which were assigned to the respective $\mathrm{H}(4 \mathrm{~b})$ signals of the major and minor products (ratio $>5: 1$ ). Chromatography afforded the crystalline lactams 12a (84\%) and<smiles>O=C(O)c1ccccc1-c1ccccc1O</smiles>

$7 \mathrm{X}=\mathrm{OH}$ $9 \mathrm{X}=\mathrm{OMe}$

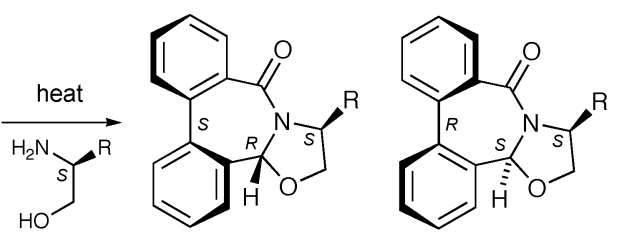

12<smiles>O=C1c2ccccc2-c2ccccc2[C@]2(O)OCC(P)N12</smiles><smiles></smiles>

14 not observed 15
Scheme 2 Condensation of the biaryls 7 and 9 with aminoalcohols $\mathbf{1 1}$.

13a $(12 \%)$, which were identified as the respective $(\mathrm{a} S, 4 \mathrm{~b} R, 7 S)$ and $(\mathrm{a} R, 4 \mathrm{~b} S, 7 S)$ diastereoisomers by X-ray crystallography. ${ }^{9}$ These lactams have highly twisted frameworks, with the aromatic rings of each biaryl unit $40-45^{\circ}$ from coplanarity and the respective carbonyls $36^{\circ}$ and $33^{\circ}$ out of the plane of the adjacent aromatic ring. The reactions of 7 with other commercial amino alcohols 11b-f also gave two lactams $\mathbf{1 2}$ and 13, each pair distinguishable through the characteristic $\mathrm{H}(4 \mathrm{~b})$ signals in their ${ }^{1} \mathrm{H}$ NMR spectra (Table 2 and Table 3), but the yields and diastereoselectivity of the process were at best moderate, leading to some isolation problems. The situation was improved using the ester-aldehyde 9, whose condensation with valinol 11a in toluene gave the lactam 12a with a d.e. of $92 \%$ (entry 7). To shorten reaction times, other condensations of 9 were carried out under more forcing conditions $\left(155^{\circ} \mathrm{C}, 3 \mathrm{~d}\right)$ which provided convenient access to the lactams $\mathbf{1 2}$ except in the case of tert-leucinol 11f (entry 12). An alternative route to the phenylglycinol-derived lactam $\mathbf{1 2 b}$ which proceeds at lower temperature, based on the activation of 7 with Mukaiyama's salt, was developed by the Levacher group. ${ }^{13}$

In principle, the condensation of 7 or 9 with an amino alcohol 11 could provide up to four diastereoisomeric lactams, and in order to rationalise the results in Table 1, in particular the absence of $\mathbf{1 4}$ and 15 from the product mixtures, the core structures 16 and 17 and the related systems 18-21 were analysed using molecular mechanics

Table 1 Condensation of the biaryls 7 and 9 with aminoalcohols 11

\begin{tabular}{|c|c|c|c|c|c|c|}
\hline Entry & Biaryl & Series & $\mathrm{R}$ & Method $^{a}$ & Products $(\text { yield }(\%))^{b}$ & Ratio $^{c}$ \\
\hline 1 & 7 & $\mathbf{a}$ & $\operatorname{Pr}^{i}$ & A & $\mathbf{1 2 a}(84), \mathbf{1 3 a}(12)$ & $84: 16$ \\
\hline 2 & 7 & b & $\mathrm{Ph}$ & A & $\mathbf{1 2 b}+\mathbf{1 3 b}(75)$ & $70: 30$ \\
\hline 4 & 7 & d & $\mathrm{Me}$ & A & $\mathbf{1 2 d}+\mathbf{1 3 d}(59)$ & $56: 44$ \\
\hline 5 & 7 & e & $\mathrm{CH}_{2} \mathrm{OBn}$ & A & $12 e+13 e(61)$ & $50: 50$ \\
\hline 6 & 7 & f & $\mathrm{Bu}^{t}$ & A & $12 \mathbf{f}+\mathbf{1 3 f}(55)$ & $64: 36$ \\
\hline 7 & 9 & a & $\operatorname{Pr}^{i}$ & $\mathrm{~A}^{d}$ & $12 \mathbf{a}+13 \mathbf{a}(71)$ & $96: 4$ \\
\hline 10 & 9 & d & $\mathrm{Me}$ & B & 12d $(72), 13 d\left(10^{e}\right)$ & $85: 15$ \\
\hline 11 & 9 & e & $\mathrm{CH}_{2} \mathrm{OBn}$ & $\mathrm{B}$ & $12 \mathrm{e}(74), 13 \mathrm{e}\left(23^{e}\right)$ & $87: 13$ \\
\hline 12 & 9 & f & $\mathrm{Bu}^{t}$ & B & $f$ & - \\
\hline
\end{tabular}

${ }^{a}$ Method A: toluene, Dean-Stark, reflux, $36 \mathrm{~h}$. Method B: xylene, bath temp. $155^{\circ} \mathrm{C}, 72 \mathrm{~h} .{ }^{b}$ Isolated yields after chromatography. ${ }^{c}$ Estimated from the ${ }^{1} \mathrm{H}$ NMR spectrum of the product mixture. ${ }^{d}$ Reflux maintained for $7 \mathrm{~d} .{ }^{e}$ Not obtained pure. ${ }^{f}$ No products observed. 


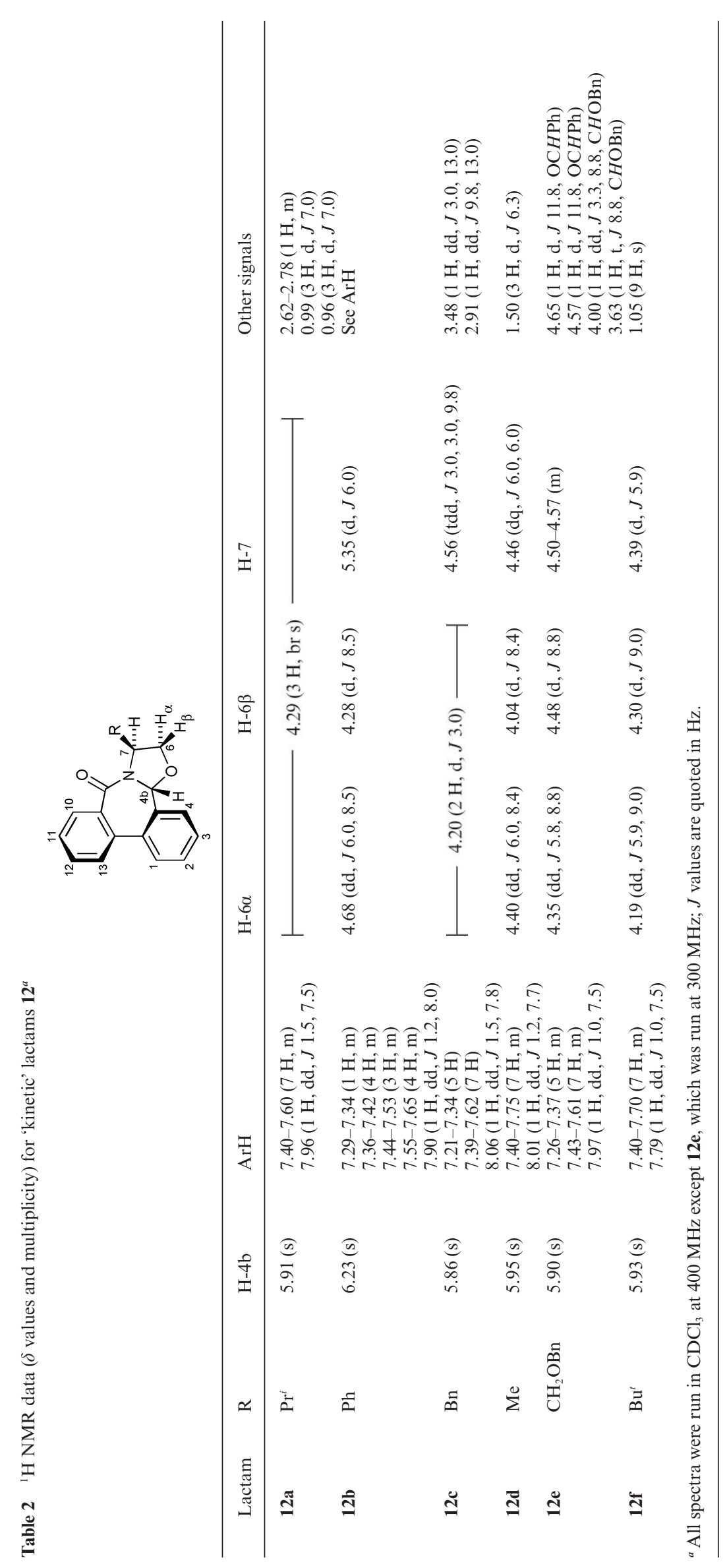








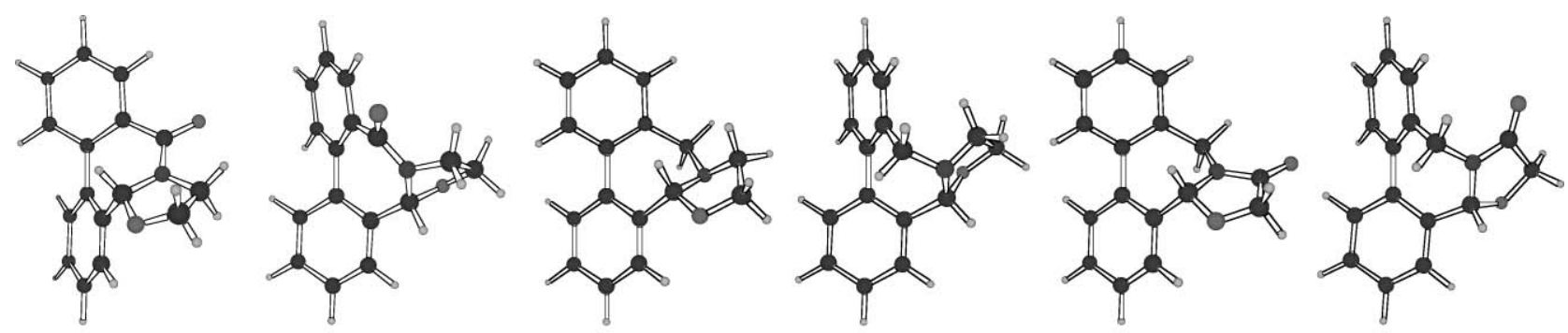

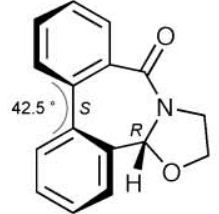

16 $104.0 \mathrm{kJmol}^{-1}$

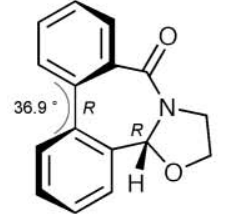

17

$214.5 \mathrm{~kJ} \mathrm{~mol}^{-1}$

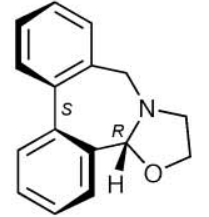

18 $118.9 \mathrm{~kJ} \mathrm{~mol}^{-1}$

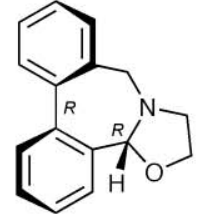

19

$118.3 \mathrm{kJmol}^{-1}$



$\stackrel{20}{27.7 \mathrm{kJmol}^{-1}}$



$55.4 \mathrm{~kJ} \mathrm{~mol}^{-1}$

Fig. 1 Energy-minimised conformations of the fused dibenzazepines 16-21 and their steric energies, calculated using MacroModel 8.0 (MM3 force field).


Fig. 2 Potential energy plots of the $\mathrm{C}(1)-\mathrm{C}(13 \mathrm{~b})-\mathrm{C}(13 \mathrm{a})-\mathrm{C}(13)$ biaryl dihedral angle (modulus) in lactams $\mathbf{1 6}$ and $\mathbf{1 7}$ in the region of their steric energy minima, calculated using MacroModel 8.0 (MM3 force field)

In an initial experiment (entry 1), the valinol-derived lactam $\mathbf{1 2 a}$ in acetonitrile- $d_{3}$ was heated to $55^{\circ} \mathrm{C}$ in the presence of a catalytic amount of $p$-toluenesulfonic acid, and the solution was monitored by ${ }^{1} \mathrm{H}$ NMR spectroscopy. The equilibration process was slow under these conditions, but the equilibration proceeded with the expected first-order kinetics (Fig. 3). The reaction was stopped after $33 \mathrm{~d}$, after which time the ratio 12a:13a was converging on a value of $1: 2$, thus confirming the greater thermodynamic stability of the diastereoisomer 13a and that the overall lactam-forming sequence (Scheme 3) was kinetically controlled.

For convenience, many of the equilibrations shown in Table 5 were carried out at higher temperatures using an excess of trifluoroacetic acid (TFA), and two blanks (entries 3 and 6 ) confirmed the requirement for acid. It is noteworthy that in all cases the isomer distribution favoured the lactam $\mathbf{1 3}$, as predicted by calculation. In some cases the calculated and observed isomer ratios were quite close, but the largest discrepancy (entry 10) serves as a reminder of the approximations made in assembling the results in Table 4: the steric energy-minimised structure of $\mathbf{1 3} \mathbf{e}$ incorporated $\pi$-stacking between the benzyl and biaryl components that would be negated by aromatic solvents.

The mechanism for acid-induced equilibration is presumed to involve the protonation of the lactam 12 followed by ring-opening to the acyliminium species $\mathbf{2 6}$, which can isomerise to $\mathbf{2 7}$ and recyclise to $\mathbf{2 8}$, providing access to $\mathbf{1 3}$ (Scheme 4). The ratedetermining step is likely to be the ring-opening of $\mathbf{2 5}$, in which the $\mathrm{C}(4 \mathrm{~b})-\mathrm{O}(5)$ bond is fixed with poor alignment for elimination.

Table 5 Acid-induced equilibration of the biaryl lactams $\mathbf{1 2}$ and $\mathbf{1 3}$

\begin{tabular}{|c|c|c|c|c|c|c|c|c|c|}
\hline Entry & Starting lactam & $\mathrm{R}$ & Solvent & Added acid & Temperature $T /{ }^{\circ} \mathrm{C}^{a}$ & Time/d & Products & Observed ratio $^{b}$ & Calculated ratio ${ }^{c}$ \\
\hline 1 & $12 a$ & $\operatorname{Pr}^{i}$ & $\mathrm{MeCN}-d_{3}$ & $p$-TsOH & 55 & $33^{d}$ & $12 a+13 a$ & $36: 64$ & $26: 74$ \\
\hline 2 & $12 a$ & $\operatorname{Pr}^{i}$ & Toluene- $d_{8}$ & $p$-TsOH & 140 & 3 & $12 a+13 a$ & $27: 73$ & $30: 70$ \\
\hline 3 & $12 a$ & $\operatorname{Pr}^{i}$ & Toluene- $d_{8}$ & None & 140 & 7 & $12 a$ & - & $30: 70$ \\
\hline 4 & $12 a$ & $\operatorname{Pr}^{i}$ & Toluene- $d_{8}$ & $\mathrm{CF}_{3} \mathrm{CO}_{2} \mathrm{H}$ & 100 & 7 & $12 a+13 a$ & $29: 71$ & $28: 72$ \\
\hline 5 & $12 b$ & $\mathrm{Ph}$ & Toluene- $d_{8}$ & $\mathrm{CF}_{3} \mathrm{CO}_{2} \mathrm{H}$ & 100 & 7 & $12 b+13 b$ & $45: 55$ & $39: 61$ \\
\hline 6 & $12 b$ & $\mathrm{Ph}$ & Xylene & None & 150 & 2 & $12 \mathrm{~b}$ & - & $40: 60$ \\
\hline 7 & $12 \mathrm{c}$ & $\mathrm{Bn}$ & Toluene- $d_{8}$ & $\mathrm{CF}_{3} \mathrm{CO}_{2} \mathrm{H}$ & 100 & 7 & $12 c+13 c$ & $36: 64$ & $27: 73$ \\
\hline 8 & $12 \mathrm{c}$ & $\mathrm{Bn}$ & $\mathrm{HCO}_{2} \mathrm{H}$ & None & 100 & $3^{d}$ & $12 c+13 c$ & $43: 57$ & $27: 73$ \\
\hline 9 & $12 d / 13 d^{e}$ & $\mathrm{Me}$ & Toluene- $d_{8}$ & $\mathrm{CF}_{3} \mathrm{CO}_{2} \mathrm{H}$ & 100 & 7 & $12 d+13 d$ & $34: 66$ & $40: 60$ \\
\hline 10 & $12 \mathrm{e} / 13 \mathrm{e}^{f}$ & $\mathrm{CH}_{2} \mathrm{OBn}$ & Xylene & $\mathrm{CF}_{3} \mathrm{CO}_{2} \mathrm{H}$ & 150 & 3 & $12 e+13 e$ & $30: 70$ & $13: 87$ \\
\hline 11 & $12 f / 13 f^{g}$ & $\mathrm{Bu}^{t}$ & Toluene & $\mathrm{CF}_{3} \mathrm{CO}_{2} \mathrm{H}$ & 100 & 7 & $12 f+13 f$ & $26: 74$ & $21: 79$ \\
\hline
\end{tabular}

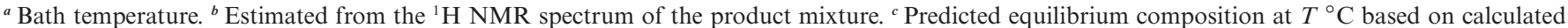
steric energies (Table 4). ${ }^{d}$ Stopped before completion. ${ }^{e}$ Starting ratio $56: 44 .{ }^{f}$ Starting ratio $50: 50 .{ }^{g}$ Starting ratio $64: 36$. 


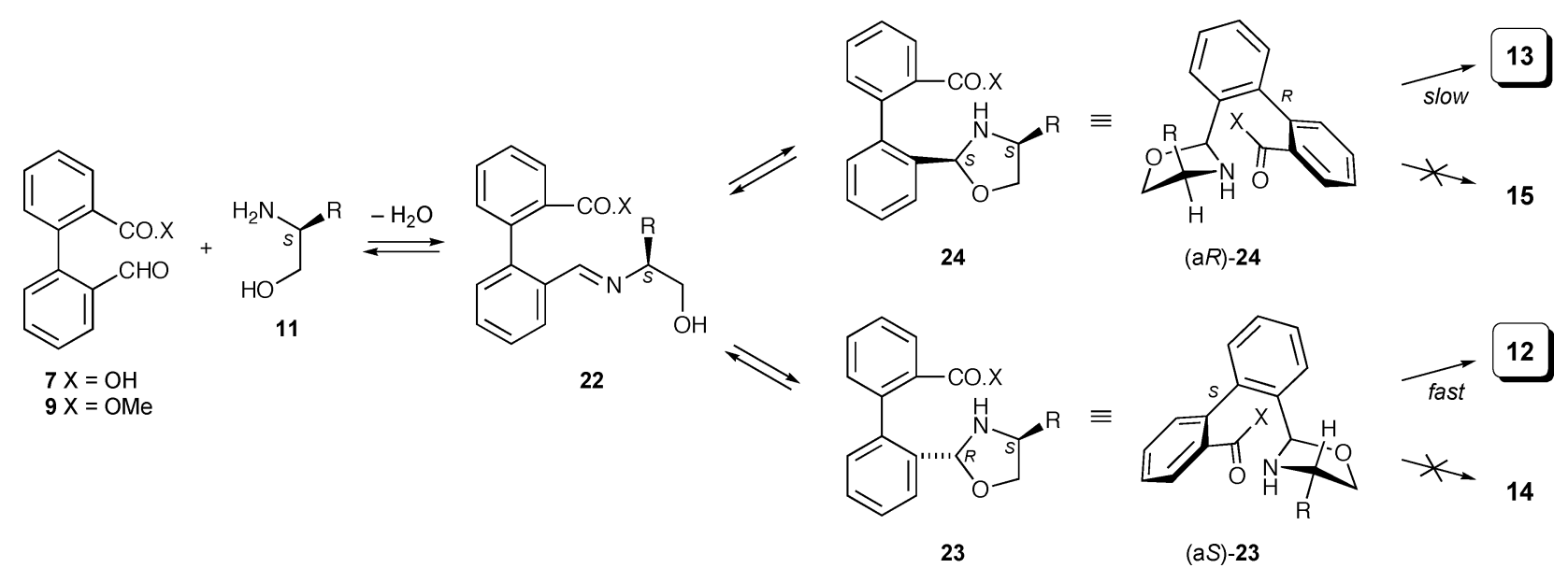

Scheme 3 Proposed mechanism for the formation of $\mathbf{1 2}$ and $\mathbf{1 3 .}$

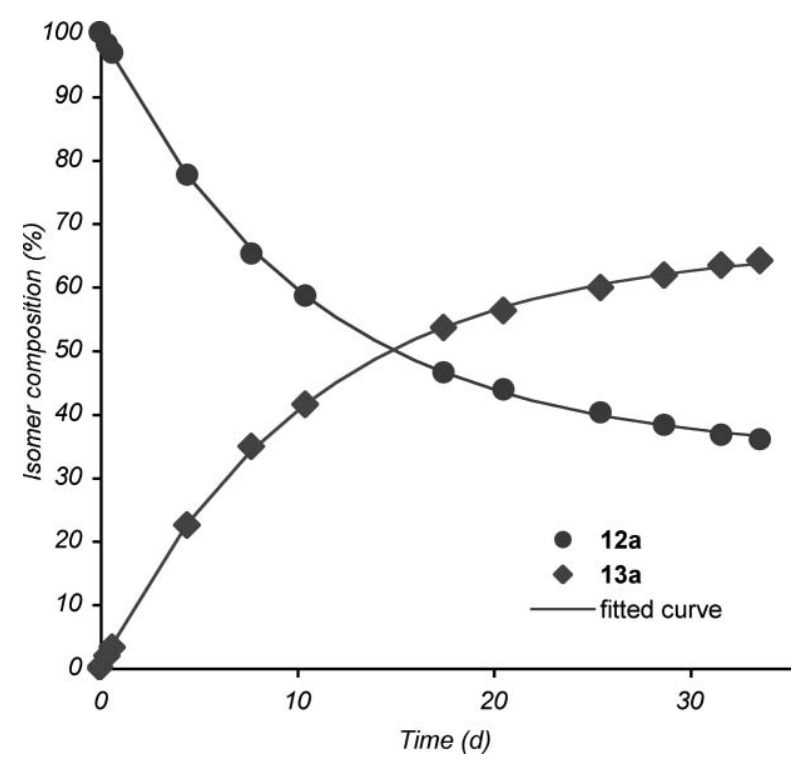

Fig. 3 The progress of the equilibration of lactams 12a and 13a in $\mathrm{CD}_{3} \mathrm{CN}$ at $55^{\circ} \mathrm{C}$. The fitted curve for [12a] corresponds to an observed rate constant $\left(k_{1}+k_{-1}\right)$ of $1.1 \times 10^{-6} \mathrm{~s}^{-1}$ and an equilibrium ratio of $1: 2$.

This can be seen in the crystal structure of $\mathbf{1 2 a}$, in which the dihedral angles $\mathrm{C}(4)-\mathrm{C}(4 \mathrm{a})-\mathrm{C}(4 \mathrm{~b})-\mathrm{O}(5)$ and $\mathrm{C}(9)-\mathrm{N}(8)-\mathrm{C}(4 \mathrm{~b})-$ $\mathrm{O}(5)$ are $3.7^{\circ}$ and $177.2^{\circ}$ respectively, i.e. the oxazolidine $\mathrm{C}-\mathrm{O}$ bond is essentially orthogonal to both the aromatic and amide $\pi$-systems (Fig. 4). The protonated oxygen therefore receives little assistance from either when operating as a leaving group. The isomer 13a is similarly situated, the corresponding dihedral angles being $2.0^{\circ}$ and $165.4^{\circ}$.<smiles>CCC[C@@H]1CO[C@@H]2c3ccccc3-c3ccccc3C(=O)N12</smiles>

$3.7^{\circ}$<smiles>CCC[C@@H]1CO[C@@H]2c3ccccc3-c3ccccc3C(=O)N12</smiles>

$177.2^{\circ}$
Fig. 4 Dihedral angles affecting $\mathrm{O}(5)$ from the X-ray crystal structure of $12 \mathbf{a} .^{9}$



Scheme 4 Proposed mechanism for the acid-catalysed equilibration of $\mathbf{1 2}$ and $\mathbf{1 3 .}$

The results of this study confirm that a mobile biaryl axis can be restrained in a predictable and fixed configuration by incorporation within a fused oxazolidine lactam of the type developed and used extensively in synthesis by Meyers et al. ${ }^{8}$ The most prominent feature of such lactams, illustrated by the properties of 12a-f and $\mathbf{1 3 a} \mathbf{a}-\mathbf{f}$, is the effectiveness of the mechanical link between the benzylic position $\mathrm{C}(4 \mathrm{~b})$ and the biaryl axis, through which stereochemical information is relayed with complete fidelity. Related chirality relays are present in the chemical literature, one such example being the cyclisation of the iminium species 29 which, on the basis of analogy with 20/21, presumably gave $( \pm)-\mathbf{3 0}$, although this was not specified. ${ }^{25}$ Other reactions of this type were reported by Hilt et al. ${ }^{26}$ who confirmed the cyclisation of $( \pm)$-31 to $( \pm)$-32 using X-ray crystallography. Only one other, non-crystalline, diastereoisomer was isolated from this reaction (d.r. $8: 1$ ) but its configuration remained unspecified. Again, by analogy with $\mathbf{2 0 / 2 1}$ the minor diastereoisomer was probably $( \pm)-\mathbf{3 3}$, as the alternative axis-centre permutation would be disfavoured due to strain. 


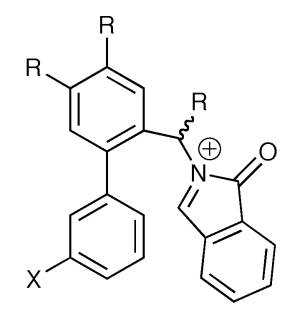

$29 \mathrm{R}=\mathrm{X}=\mathrm{H}$

$31 \mathrm{R}=\mathrm{Me}, \mathrm{X}=\mathrm{OMe}$

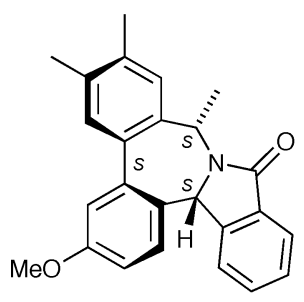

32

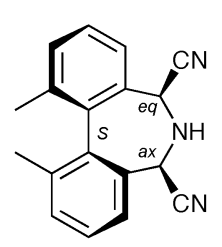

34

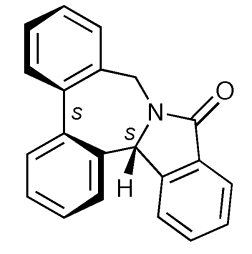

30

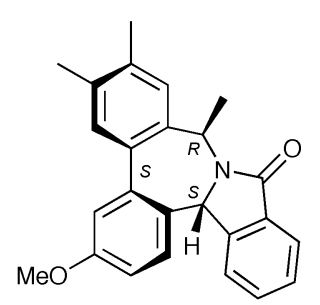

33

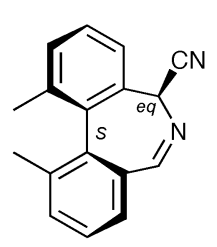

35
The most intriguing illustration of benzylic centre-axis complementarity is the observation by Zavada and co-workers that the zinc bromide-induced elimination of cyanide ion from the fixedaxis biaryl 34 produces only 35 , indicating that only the axial cyano group is expelled. ${ }^{27}$ Moreover, the reverse reaction, in which 35 undergoes the addition of cyanide ion, is also completely selective, regenerating 34 in the absence of stereoisomers. The centre-axis stereochemical relay thus operates in both directions, with the configuration of the axis dictating the orbital alignment of the imine moiety in $\mathbf{3 5}$.

\section{Conclusions}

The formation of biaryl-fused lactams $\mathbf{1 2}$ via the mechanism shown in Scheme 3 amounts to the dynamic kinetic resolution of 7 or 9, whose flexible biaryl axis is converged to a single configuration in the form of the derived lactam 12. The overall sequence involves the relay of chirality from the auxiliary amino alcohol 11 to the benzylic fusion position, C(4b), which proceeds with kinetic selectivity (up to $92 \%$ d.e.) originating in the faster cyclisation of $(\mathrm{a} S)-\mathbf{2 3}$ as compared to $(\mathrm{a} R)-\mathbf{2 4}$. The alternative cyclisations of 23 through an $(R)$-configured axis to give 14, and of $\mathbf{2 4}$ through an $(S)$-configured axis to give $\mathbf{1 5}$, are prohibited by strain, which is manifested in the lactams $\mathbf{1 2}$ and $\mathbf{1 3}$ as a chirality relay of unit efficiency between $\mathrm{C}(4 \mathrm{~b})$ and the biaryl axis. The diastereoisomeric pairs in each lactam series can be interconverted by heating with acid, leading to equilibrium mixtures in which $\mathbf{1 3}$ generally predominates by $c a .3: 1$.

Given the established advantages of amino alcohols as chiral auxiliaries, based on their ready availability in enantiopure form and the methods by which they can be installed, exploited and disconnected, ${ }^{8}$ biaryl-fused oxazolidine lactams of the forms $\mathbf{1 2}$ and $\mathbf{1 3}$ could be useful in a variety roles that require robust, conformationally defined chiral frameworks. Experiments designed to explore the chemistry of these lactams, with particular emphasis on processes that allow the retention of the induced axial chirality after disconnection of the oxazolidine ring, are in progress and will be reported in due course.

\section{Experimental}

Melting points were determined using a Kofler hot-stage or an Electrothermal apparatus and are uncorrected. IR spectra were recorded for neat thin films on $\mathrm{NaCl}$ plates, using Perkin-Elmer 1710FT or Nicolet Nexus 670/870 spectrometers. NMR spectra were measured on Bruker DPX200, AC300 and Advance 400 instruments for solutions in deuteriochloroform, unless otherwise indicated; resonances were assigned with the aid of COSY, HMBC, HMQC and DEPT spectra where appropriate. Low-resolution mass spectra were measured on a Micromass LCT instrument using a Waters 2790 separations module with electrospray $\left(\mathrm{ES}^{+}\right)$ ionisation and TOF fragment detection. High-resolution mass spectra were recorded on ThermoFinnigan MAT95XP or Kratos Concept S1 instruments. Data for most of the peaks of intensity $<20 \%$ of that of the base peak are omitted. Elemental analyses were carried out by the UMIST and University of Manchester microanalytical services. Optical rotations were measured at $589 \mathrm{~nm}$ using an AA-100 polarimeter (Optical Activity Ltd). The sealed tubes used in equilibration experiments were screw-capped and made from thick-walled glass (Aldrich Z18106-4).

Starting materials and solvents were routinely purified by conventional techniques ${ }^{28}$ and most reactions were carried out under nitrogen or argon. Organic solutions were dried using anhydrous magnesium sulfate and concentrated by rotary evaporation. Analytical thin layer chromatography (TLC) was carried out on Merck silica gel 60 on aluminium plates containing a $254 \mathrm{~nm}$ fluorescent indicator. The chromatograms were visualised by the use of UV light or the following developing agents: ethanolic vanillin or potassium permanganate. Unless otherwise indicated, preparative (column) chromatography was carried out using the flash technique ${ }^{29}$ on $60 \mathrm{H}$ silica gel (Merck 9385). Compositions of solvent mixtures are quoted as ratios of volume. 'Petroleum' refers to a light petroleum fraction, b.p. $40-60{ }^{\circ} \mathrm{C}$, unless otherwise stated. 'Ether' refers to diethyl ether. 'Xylene' refers to anhydrous $o$-xylene (Aldrich 294780).

\section{$2^{\prime}$-(Hydrazinocarbonyl)biphenyl-2-carboxylic acid $6^{14}$}

To a solution of hydrazine monohydrate $(4.0 \mathrm{~mL}, 82.5 \mathrm{mmol})$ in water $(4 \mathrm{~mL})$ at $0{ }^{\circ} \mathrm{C}$ was added diphenic anhydride $5(8.00 \mathrm{~g}$, $35.7 \mathrm{mmol}$ ) over a period of $5 \mathrm{~min}$ with vigorous stirring and then the mixture was heated to $90{ }^{\circ} \mathrm{C}$ for $1 \mathrm{~h}$. The reaction was cooled and poured into water $(50 \mathrm{~mL})$. The solution was acidified with conc. $\mathrm{HCl}$ to $\mathrm{pH} 2$ with vigorous stirring until a gummy brown solid began to form. Chilling and scratching gave a fine white precipitate. Filtration and crystallisation $(\mathrm{EtOH})$ gave the monohydrazide $6(8.70 \mathrm{~g}, 95 \%)$ as a colourless solid, m.p. 182.5$183{ }^{\circ} \mathrm{C}$ (Found: $\mathrm{C}, 65.4 ; \mathrm{H}, 5.0 ; \mathrm{N}, 10.6 . \mathrm{C}_{14} \mathrm{H}_{12} \mathrm{~N}_{2} \mathrm{O}_{3}$ requires $\mathrm{C}$, 65.62; H, 4.72; N, 10.93\%); $v_{\max } / \mathrm{cm}^{-1} 3269,3165 ; \delta_{\mathrm{H}}(300 \mathrm{MHz}$, $\left.\mathrm{CDCl}_{3}\right) 7.76(1 \mathrm{H}, \mathrm{dd}, J 1.5,7.5 \mathrm{~Hz}, \mathrm{ArH}), 7.52-7.38(5 \mathrm{H}, \mathrm{m}$, $\mathrm{ArH}), 7.14-7.09$ (3 H, m, ArH); $\delta_{\mathrm{C}}\left(100 \mathrm{MHz}, \mathrm{CDCl}_{3}\right)$ 127.4, 
127.6, 129.3, 129.6, 130.3, 130.6, 130.9, 132.3, 134.3, 140.4, 140.9, $168.2,169.1 ; m / z 279\left([\mathrm{M}+\mathrm{Na}]^{+}, 25 \%\right), 257\left([\mathrm{M}+\mathrm{H}]^{+}, 18\right), 239$ $(100) ; R_{\mathrm{f}} 0.20($ EtOAc-EtOH, $3: 2)$.

\section{$2^{\prime}$-Formylbiphenyl-2-carboxylic acid $7^{15}$}

To a cooled solution $\left(0{ }^{\circ} \mathrm{C}\right)$ of periodic acid $\left(\right.$ as $\mathrm{H}_{5} \mathrm{IO}_{6}, 1.54 \mathrm{~g}$, $6.8 \mathrm{mmol})$ in water $(36 \mathrm{~mL})$ and aq. ammonium hydroxide $(8 \%$ $\mathrm{w} / \mathrm{w}, 14 \mathrm{~mL})$ was added the hydrazide $6(1.0 \mathrm{~g}, 3.9 \mathrm{mmol})$ dissolved in aq. ammonium hydroxide $(8 \% \mathrm{w} / \mathrm{w}, 7 \mathrm{~mL})$ with vigorous stirring, keeping the temperature below $5{ }^{\circ} \mathrm{C}$. The mixture was stirred at $5^{\circ} \mathrm{C}$ for $5 \mathrm{~min}$ and then at room temperature for $15 \mathrm{~min}$. Conc. sulfuric acid ( $c a .6 \mathrm{~mL}$ ) was added, producing a gummy brown solid, which was dissolved in dichloromethane $(30 \mathrm{~mL})$. The layers were separated, the aqueous layer was extracted with dichloromethane $(3 \times 30 \mathrm{~mL})$, and the combined organic phase was dried over $\mathrm{MgSO}_{4}$ and evaporated. Chromatography of the residual brown oil ( $80 \mathrm{~g} \mathrm{SiO}_{2}$, EtOAc-dichloromethane $\left.1: 4\right)$ and crystallisation from EtOAc gave the title compound 7 (440 mg, $50 \%$ ) as a white solid, m.p. $134-136^{\circ} \mathrm{C}\left[\right.$ lit. $^{16} 134-135^{\circ} \mathrm{C}(\mathrm{MeOH}-$ water)] (Found: $\mathrm{C}, 74.1 ; \mathrm{H}, 4.6 . \mathrm{C}_{14} \mathrm{H}_{10} \mathrm{O}_{3}$ requires $\mathrm{C}, 74.33 ; \mathrm{H}$, $4.46 \%) ; v_{\max } / \mathrm{cm}^{-1} 3064,2843,1728,1689,1596,1402,1274,1200$, $757 ; \delta_{\mathrm{H}}\left(300 \mathrm{MHz}, \mathrm{CDCl}_{3}\right) 10.30(1 \mathrm{H}, \mathrm{s}, \mathrm{OH}), 9.78(1 \mathrm{H}, \mathrm{s}, \mathrm{CHO})$, 8.11 (1 H, dd, J 1.4, 7.9 Hz, ArH), 7.99 (1 H, dd, J 1.5, 7.5 Hz, ArH), 7.62-7.48 (4 H, m, ArH), 7.30 (1 H, dd, J 1.2, 7.5 Hz, ArH), $7.23(1 \mathrm{H}, \mathrm{dd}, J 1.1,7.5 \mathrm{~Hz}, \mathrm{ArH}) ; \delta_{\mathrm{C}}\left(75 \mathrm{MHz}, \mathrm{CDCl}_{3}\right) 128.0$, 128.3, 128.6, 129.6, 130.4, 131.5, 132.3, 132.7, 133.6, 134.1, 140.6, $145.2,172.2,192.1 ; \mathrm{m} / \mathrm{z} 290\left(\left[\mathrm{M}+2 \mathrm{Na}+\mathrm{H}_{2} \mathrm{O}\right]^{+}, 100 \%\right), 249([\mathrm{M}+$ $\mathrm{Na}]^{+}, 30$ ), 209 (6), 181 (50); $R_{\mathrm{f}} 0.20$ (EtOAc-dichloromethane, $1: 4)$.

\section{Methyl 2'-hydroxymethylbiphenyl-2-carboxylate 8}

A stirred suspension of diphenic anhydride 5 (3.52 g, $15.7 \mathrm{mmol})$ in $\mathrm{MeOH}(50 \mathrm{~mL})$ was heated to reflux for $3.3 \mathrm{~h}$. The resulting solution was concentrated in vacuo to yield a dark oil. To a stirred solution of this oil in THF $(100 \mathrm{~mL})$ at $0{ }^{\circ} \mathrm{C}$ was added dropwise a solution of borane-dimethylsulfide in THF $(2 \mathrm{M}, 14.1 \mathrm{~mL}$, $28.2 \mathrm{mmol}$ ) and the resulting solution was allowed to warm to room temperature over $23.5 \mathrm{~h}$. The mixture was cautiously quenched with $\mathrm{MeOH}(10 \mathrm{~mL})$ and the volatiles removed in vacuo. The residue was diluted with EtOAc $(100 \mathrm{~mL})$ and washed with saturated aqueous $\mathrm{NaHCO}_{3}(2 \times 50 \mathrm{~mL})$. The organic phase was dried, filtered, concentrated in vacuo and purified by chromatography (EtOAc-hexane, $1: 3)$, which gave the title compound 8 (2.56 g, 67\% over two steps) as a colourless oil; $\delta_{\mathrm{H}}$ $\left(300 \mathrm{MHz}, \mathrm{CDCl}_{3}\right) 7.94(1 \mathrm{H}, \mathrm{dd}, J 0.8,7.5 \mathrm{~Hz}, 6-\mathrm{H}), 7.58-7.22$ (6 H, m, ArH), 7.06 (1 H, d, J $\left.6.8 \mathrm{~Hz}, 3^{\prime}-\mathrm{H}\right), 4.44(1 \mathrm{H}, \mathrm{d}, J$ $\left.12.1 \mathrm{~Hz}, \mathrm{CH} \mathrm{H}^{\prime} \mathrm{OH}\right), 4.38$ (1 H, d, J $\left.12.1 \mathrm{~Hz}, \mathrm{CH} H^{\prime} \mathrm{OH}\right), 3.67(3 \mathrm{H}$, $\left.\mathrm{s}, \mathrm{OCH}_{3}\right), 1.94(1 \mathrm{H}, \mathrm{s}, \mathrm{OH})$ (in accord with published data $\left.{ }^{17}\right) ; R_{\mathrm{f}}$ 0.23 (EtOAc-hexane, $3: 7$ ).

\section{Methyl 2'-formylbiphenyl-2-carboxylate 9}

Method A (ref. 18). To a stirred solution of the ester-alcohol $8(2.56 \mathrm{~g}, 10.6 \mathrm{mmol})$ in dichloromethane $(200 \mathrm{~mL})$ was added $\mathrm{MnO}_{2}(80 \%$ pure; $10.82 \mathrm{~g}, 0.10 \mathrm{~mol})$ and the resulting suspension was heated under reflux for $3 \mathrm{~h}$. The reaction mixture was cooled to room temperature, filtered through Celite and concentrated in vacuo to yield a mixture (ca. $1: 1)$ of $\mathbf{9}$ and $\mathbf{1 0}(2.36 \mathrm{~g})$ as a colourless oil. Chromatography (EtOAc-hexane, $15: 85$ ) gave a sample of the ester-aldehyde 9 (484 mg, 19\%) as a colourless oil; $\delta_{\mathrm{H}}(300 \mathrm{MHz}$, $\left.\mathrm{CDCl}_{3}\right) 9.81(1 \mathrm{H}, \mathrm{s}, \mathrm{CHO}), 8.06(1 \mathrm{H}, \mathrm{d}, J 7.0 \mathrm{~Hz}, \mathrm{ArH}), 8.02(1 \mathrm{H}$, d, J 7.9 Hz, ArH), 7.64-7.50 (4 H, m, ArH), $7.30(1 \mathrm{H}, \mathrm{d}, J 7.5 \mathrm{~Hz}$, ArH), 7.26 (1 H, d, J 8.7 Hz, ArH), 3.63 (3 H, s, OMe); $v_{\max } / \mathrm{cm}^{-1}$ 3062, 2951, 2842, 2751, 1728, 1696, 1596, 1435, 1258, 1196, 1129, 1086, 761, 668; $R_{\mathrm{f}} 0.52$ (EtOAc-hexane, $3: 7$ ). Further elution of the column yielded a mixed fraction $(1.45 \mathrm{~g}, 61 \%)$ followed by $7 \mathrm{H}$ dibenzo[c,e]oxepin-5-one 10 (425 mg, 19\%) as white crystals, m.p. $132-135{ }^{\circ} \mathrm{C}\left[\right.$ lit. $^{30} 132-134{ }^{\circ} \mathrm{C}$ (sublimed)]; $\delta_{\mathrm{H}}\left(300 \mathrm{MHz}, \mathrm{CDCl}_{3}\right.$ ) 7.98 (1 H, d, J 7.9 Hz, ArH), 7.70-7.40 (7 H, m, ArH), $5.03(2 \mathrm{H}$, br d, $J 15.5 \mathrm{~Hz}, 7-\mathrm{H}_{2}$ ) (in accord with published data ${ }^{31}$ ); $v_{\max } / \mathrm{cm}^{-1}$ 3069, $1716(\mathrm{C}=\mathrm{O}), 1600,1449,1379,1277,1226,1111,1091,1048$, 1011, 765, 740; $R_{\mathrm{f}} 0.42$ (EtOAc-hexane, $3: 7$ ).

Method B. A solution of DMSO $(0.51 \mathrm{~mL}, 561 \mathrm{mg}, 7.2 \mathrm{mmol}$, 1.3 eq. $)$ in dichloromethane $(3 \mathrm{~mL})$ was added to a $2 \mathrm{M}$ solution of oxalyl dichloride $(3 \mathrm{~mL}, 6.0 \mathrm{mmol})$ in dichloromethane $(20 \mathrm{~mL})$ at $-78{ }^{\circ} \mathrm{C}$ and stirred for $30 \mathrm{~min}$. The ester-alcohol $8(1.33 \mathrm{~g}$, $5.5 \mathrm{mmol})$ in dichloromethane $(5 \mathrm{~mL})$ was added and the reaction mixture stirred for a further $30 \mathrm{~min}$ at $-78{ }^{\circ} \mathrm{C}$. Triethylamine ( $2 \mathrm{~mL}, 1.45 \mathrm{~g}, 14.3 \mathrm{mmol}$ ) was added and the reaction mixture was allowed to warm to room temperature while stirring for $3 \mathrm{~h}$. The mixture was quenched with aq. ammonium chloride $(2 \mathrm{M}, 20 \mathrm{~mL})$, extracted with dichloromethane $(3 \times 30 \mathrm{ml})$, dried $\left(\mathrm{Na}_{2} \mathrm{SO}_{4}\right)$ and concentrated, giving the ester-aldehyde 9 as a pale yellow oil (1.20 g, 91\%), identical (TLC, ${ }^{1} \mathrm{H}$ NMR) to material obtained using Method A above.

\section{Formation of biaryl lactams (Table 1)}

Method A. From the acid-aldehyde 7 in toluene: A solution of 2'-formylbiphenyl-2-carboxylic acid 7 and the appropriate aminoalcohol 11 (1.4-1.5 mol. equiv.) in toluene was heated under reflux in a Dean-Stark apparatus for $36 \mathrm{~h}$. The solution was cooled, evaporated in vacuo and the residue was analysed by ${ }^{1} \mathrm{H}$ NMR spectroscopy to determine the diastereoisomer ratio (see Table 2 and Table 3 for ${ }^{1} \mathrm{H}$ NMR data). The products were isolated by chromatography over silica gel.

Method B. From the ester-aldehyde 9 in xylene: A solution of methyl 2'-formylbiphenyl-2-carboxylate 9 and the appropriate aminoalcohol 11 (1.4-1.5 mol. equiv.) in xylene was heated at $155^{\circ} \mathrm{C}$ (bath temp.) for $3 \mathrm{~d}$. The solution was cooled, evaporated in vacuo and the residue was analysed by ${ }^{1} \mathrm{H}$ NMR spectroscopy to determine the diastereoisomer ratio. The products were isolated by chromatography over silica gel.

\section{(a $S, 4 \mathrm{~b} R, 7 S)-6,7-D i h y d r o-7-i s o p r o p y l d i b e n z[c, e]$ oxazolo[3,2- a]azepin-9 $(4 \mathrm{~b} H)$-one $12 \mathrm{a}$ and $(\mathrm{a} R, 4 \mathrm{~b} S, 7 S)-6,7-d i h y d r o-7-$ isopropyldibenz $[c, e]$ oxazolo[3,2-a]azepin-9(4bH)-one 13a}

Method A. The acid-aldehyde 7 (280 mg, $1.24 \mathrm{mmol})$ and $(S)$ valinol 11a $(180 \mathrm{mg}, 1.74 \mathrm{mmol})$ in toluene $(16 \mathrm{~mL})$ was heated under reflux in a Dean-Stark apparatus under Ar for $36 \mathrm{~h}$. TLC indicated complete conversion, the reaction was cooled and the solvent removed in vacuo. The residue was partially purified by chromatography over silica gel $\left(80 \mathrm{~g} \mathrm{SiO}_{2}\right.$, EtOAc-hexane $1: 5$ as eluant), which gave the title compound 12a (210 $\mathrm{mg}, 58 \%)$ as colourless crystals, m.p. $121-123{ }^{\circ} \mathrm{C}$ (EtOAc) (Found: C, 77.7; H, 
6.8; N, 5.0. $\mathrm{C}_{19} \mathrm{H}_{19} \mathrm{NO}_{2}$ requires $\left.\mathrm{C}, 77.79 ; \mathrm{H}, 6.53 ; \mathrm{N}, 4.77 \%\right) ;[\alpha]_{\mathrm{D}}^{23}$ $-183 \pm 7$ (c 1.9, $\left.\mathrm{CHCl}_{3}\right) ; v_{\max } / \mathrm{cm}^{-1} 3068,2959,2885,1639,1600$, $1449,1406,1289,1216,1173,1080,854 ; \delta_{\mathrm{C}}\left(75 \mathrm{MHz}, \mathrm{CDCl}_{3}\right) 16.5$ $\left(\mathrm{Me}_{\mathrm{A}}\right), 19.8\left(\mathrm{Me}_{\mathrm{B}}\right), 28.0\left(\mathrm{CHMe}_{2}\right), 61.9(7-\mathrm{C}), 67.2(6-\mathrm{C}), 86.6$ (4b-C), 122.3, 128.4 (two), 129.2, 129.4, 130.0, 130.2 and 131.4 $(\mathrm{ArCH}), 135.7,136.2,136.6$ and 139.0 (quaternary $\mathrm{ArC}$ ), 164.5 $(8-\mathrm{C}) ; m / z 609\left([2 \mathrm{M}+\mathrm{Na}]^{+}, 100 \%\right), 357(79), 294\left([\mathrm{M}+\mathrm{H}]^{+}, 82\right)$; $R_{\mathrm{f}} 0.30$ (EtOAc-hexane, $1: 4$ ). Mixed fractions were condensed to give an oil (139 mg, 38\%) which was purified by preparative TLC [20 $\times 20 \times 0.02 \mathrm{~cm}($ Merck 1.05583); multiple elution with EtOAchexane $1: 6]$, giving 12a (95 $\mathrm{mg}, 26 \%)$ and the title compound 13a (42 mg, $11.5 \%$ ), m.p. $114-115{ }^{\circ} \mathrm{C}$ (petroleum, b.p. $60-80{ }^{\circ} \mathrm{C}$ ) (Found: $\mathrm{C}, 78.0 ; \mathrm{H}, 6.8 ; \mathrm{N}, 5.0 . \mathrm{C}_{19} \mathrm{H}_{19} \mathrm{NO}_{2}$ requires $\mathrm{C}, 77.79 ; \mathrm{H}$, 6.53; N, 4.77\%); $[\alpha]_{\mathrm{D}}^{27}+148 \pm 5\left(c 2.25, \mathrm{CHCl}_{3}\right) ; v_{\max } / \mathrm{cm}^{-1} 3064$, 2959, 2874, 1639, 1596, 1445, 1402, 1344, 1169, 1080, 994, 963, 858, 742, 703; $\delta_{\mathrm{C}}\left(75 \mathrm{MHz}, \mathrm{CDCl}_{3}\right) 18.7(\mathrm{Me}), 19.7(\mathrm{Me}), 30.7$ $\left(\mathrm{CHMe}_{2}\right), 63.0$ (7-C), 69.5 (6-C), 86.1 (4b-C), 122.5, 128.3, 128.4, 129.1, 129.7, 130.3, 130.7 and $131.8(\mathrm{ArCH}), 134.1,136.2,137.6$ and 139.3 (quaternary $\mathrm{ArC}$ ), $165.4(8-\mathrm{C}) ; \mathrm{m} / z 609\left([2 \mathrm{M}+\mathrm{Na}]^{+}\right.$, $100 \%), 357(88), 294\left([\mathrm{M}+\mathrm{H}]^{+}, 81\right) ; R_{\mathrm{f}} 0.28$ (EtOAc-hexane, $1: 4)$.

From ester 9. Heating the ester-aldehyde 9 (230 mg, $0.96 \mathrm{mmol})$ and $(S)$-valinol 11a $(148 \mathrm{mg}, 1.43 \mathrm{mmol})$ in toluene $(15 \mathrm{~mL})$ under reflux (bath temp. $120^{\circ} \mathrm{C}$ ) for $7 \mathrm{~d}$ gave the mixed lactams 12a and 13a (total $200 \mathrm{mg}, 71 \%$, ratio $96: 4$ ).

(aS,4bR,7S)-6,7-Dihydro-7-phenyldibenz[c,e]oxazolo[3,2$a \mid$ azepin-9 $(4 \mathrm{~b} H)$-one $12 \mathrm{~b}$ and $(\mathrm{a} R, 4 \mathrm{~b} S, 7 S)-6,7-d i h y d r o-7-$ phenyldibenz $[c, e]$ oxazolo[3,2-a]azepin-9(4bH)-one 13b

Method A. Heating the acid-aldehyde 7 (296 mg, $1.31 \mathrm{mmol})$ and the amino alcohol $11 \mathbf{b}(270 \mathrm{mg}, 1.97 \mathrm{mmol})$ in toluene $(15 \mathrm{~mL})$ under reflux (bath temp. $120{ }^{\circ} \mathrm{C}$ ) for $36 \mathrm{~h}$ gave the mixed lactams 12b and 13b (total $320 \mathrm{mg}, 75 \%$, ratio $70: 30$ ).

Method B. Heating the ester-aldehyde 9 (100 mg, $0.42 \mathrm{mmol})$ and $(S)$-phenylglycinol $11 b(86 \mathrm{mg}, 0.63 \mathrm{mmol})$ in xylene $(5 \mathrm{~mL})$ at $155{ }^{\circ} \mathrm{C}$ (bath temp.) for $3 \mathrm{~d}$ followed by removal of the solvent in vacuo gave a mixture of isomeric lactams (ratio 91 : 9). Chromatography (EtOAc-hexane, $1: 4)$ gave the title compound 12b $(120 \mathrm{mg}, 88 \%)$ as colourless needles, m.p. $143-145^{\circ} \mathrm{C}(\mathrm{MeOH})$ (lit. $\left.{ }^{13} 138-140{ }^{\circ} \mathrm{C}\right) ;[a]_{\mathrm{D}}^{28}-86 \pm 8\left(c 0.26, \mathrm{CHCl}_{3}\right) ; v_{\max } / \mathrm{cm}^{-1} 3662$, 3471, 3269, 3067, 3021, 2948, 2889, 1638, 1452, 1398, 1339, 1277, $1211,1157,904,737 ; \delta_{\mathrm{C}}\left(100 \mathrm{MHz}, \mathrm{CDCl}_{3}\right) 60.2$ (6-C), 74.0 (7-C), 86.6 (4b-C), 121.8, 126.3 (two), 127.8, 128.2 (two), 128.8 (two), 129.1, 129.4, 130.0, 130.2 and 131.4 (ArCH), 134.8, 136.2, 136.4, 138.3 and 140.8 (quaternary $\mathrm{ArC}$ ), 163.7 (8-C); $\mathrm{m} / \mathrm{z} 677$ ([2M + $\left.\mathrm{Na}]^{+}, 49\right), 510(53), 391\left(\left[\mathrm{M}+2 \mathrm{Na}+\mathrm{H}_{2} \mathrm{O}\right]^{+}, 58\right), 355$ (100), $350\left([\mathrm{M}+\mathrm{Na}]^{+}, 82\right), 329$ (76), 235 (73), 207 (38) (Found: $\mathrm{M}+$ $\mathrm{Na}, 350.1145 ; \mathrm{C}_{22} \mathrm{H}_{17} \mathrm{O}_{2} \mathrm{NNa}$ requires 350.1152); $R_{\mathrm{f}} 0.25$ (EtOAchexane, $3: 7)$.

(aS,4b $R, 7 S)-6,7-D i h y d r o-7-(p h e n y l m e t h y l)$ dibenz $[c, e]$ oxazolo[3,2a]azepin-9(4bH)-one 12c and $(\mathrm{a} R, 4 \mathrm{~b} S, 7 S)-6,7-d i h y d r o-7-$ (phenylmethyl)dibenz $[c, e]$ oxazolo[3,2-a]azepin-9(4bH)-one 13c

Method A. Heating the acid-aldehyde 7 (260 mg, $1.15 \mathrm{mmol})$ and $(S)$-phenylalaninol 11c $(260 \mathrm{mg}, 1.72 \mathrm{mmol})$ in toluene $(15 \mathrm{~mL})$ under reflux (bath temp. $120^{\circ} \mathrm{C}$ ) for $36 \mathrm{~h}$ gave the mixed lactams $12 \mathrm{c}$ and $\mathbf{1 3 c}$ (total $210 \mathrm{mg}, 54 \%$ ), ratio $62: 38$ by ${ }^{1} \mathrm{H}$ NMR spectroscopy.

Method B. Heating the ester-aldehyde $9(110 \mathrm{mg}, 0.46 \mathrm{mmol})$ and $(S)$-phenylalaninol 11c (104 mg, $0.69 \mathrm{mmol})$ in xylene $(5 \mathrm{~mL})$ at $155{ }^{\circ} \mathrm{C}$ (bath temp.) for $3 \mathrm{~d}$ followed by removal of the solvent in vacuo gave a mixture of isomeric lactams (ratio 92 : 8). Chromatography (EtOAc-hexane, $15: 85$ ) gave the title compound 12c (129 mg, 83\%) as a colourless solid, m.p. 84 $84.5{ }^{\circ} \mathrm{C}$ (dichloromethane) (Found: C, 80.75; H, 5.67; N, 4.03. $\mathrm{C}_{23} \mathrm{H}_{19} \mathrm{NO}_{2}$ requires $\left.\mathrm{C}, 80.92 ; \mathrm{H}, 5.61 ; \mathrm{N}, 4.10 \%\right) ;[\alpha]_{\mathrm{D}}^{26}-226 \pm 9$ $\left(c 1.0, \mathrm{CHCl}_{3}\right) ; v_{\max } / \mathrm{cm}^{-1} 3069,2927,1638,1447,1406,750 ; \delta_{\mathrm{C}}$ $\left(100 \mathrm{MHz} \mathrm{CDCl}_{3}\right) 37.0\left(\mathrm{PhCH}_{2}\right), 58.2$ (7-C), 69.4 (6-C), 86.0 (4bC), 121.7, 126.7, 128.13, 128.15, 128.7 (two), 128.9, 129.4, 129.6 (two), 129.9, 130.0 and 131.3 ( $\mathrm{ArCH}), 134.8,136.1,136.2,137.9$ and 138.4 (quaternary $\operatorname{ArC}), 163.9(8-\mathrm{C}) ; m / z 705\left([2 \mathrm{M}+\mathrm{Na}]^{+}\right.$, $46 \%), 405\left(\left[\mathrm{M}+2 \mathrm{Na}+\mathrm{H}_{2} \mathrm{O}\right]^{+}, 69\right), 364\left([\mathrm{M}+\mathrm{Na}]^{+}, 100\right), 342([\mathrm{M}+$ $\mathrm{H}]^{+}$, 82) (Found: $\mathrm{M}, 341.1416 ; \mathrm{C}_{23} \mathrm{H}_{19} \mathrm{O}_{2} \mathrm{~N}$ requires 341.1410); $R_{\mathrm{f}}$ 0.38 (EtOAc-hexane, $3: 7$ ). Further elution of the column yielded a mixed fraction (11 mg, 7\%) and the title compound $13 \mathbf{c}(9 \mathrm{mg}$, $6 \%$ ) as a colourless oil; $v_{\max } / \mathrm{cm}^{-1} 2913,2844,1642,1448,1081$; $\delta_{\mathrm{C}}\left(100 \mathrm{MHz}, \mathrm{CDCl}_{3}\right) 38.5\left(\mathrm{CH}_{2} \mathrm{Ph}\right), 58.5$ (7-C), 70.5 (6-C), 85.8 (4b-C), 121.9, 126.7, 128.2, 128.4, 128.7 (two), 128.9, 129.5 (two), 129.6, 129.8, 130.2 and 131.5 (ArCH), 133.9, 135.9, 137.2, 137.8 and 139.4 (quaternary $\operatorname{ArC}$ ), $164.2(8-\mathrm{C}) ; m / z 705\left([2 \mathrm{M}+\mathrm{Na}]^{+}\right.$, $11 \%), 405\left(\left[\mathrm{M}+2 \mathrm{Na}+\mathrm{H}_{2} \mathrm{O}\right]^{+}, 47\right), 364\left([\mathrm{M}+\mathrm{Na}]^{+}, 96\right), 342([\mathrm{M}+$ $\mathrm{H}]^{+}, 100$ ) (Found: $\mathrm{M}, 341.1412 ; \mathrm{C}_{23} \mathrm{H}_{19} \mathrm{O}_{2} \mathrm{~N}$ requires 341.1410); $R_{\mathrm{f}}$ 0.31 (EtOAc-hexane, $3: 7$ ).

(aS,4bR,7S)-6,7-Dihydro-7-methyldibenz[c,e]oxazolo[3,2a]azepin-9(4bH)-one 12d and (aR,4bS,7S)-6,7-dihydro-7methyldibenz $[c, e]$ oxazolo[3,2-a]azepin-9(4bH)-one 13d

Method A. Heating the acid-aldehyde $7(290 \mathrm{mg}, 1.28 \mathrm{mmol})$ and $(S)$-2-amino-1-propanol 11d (144 mg, $1.92 \mathrm{mmol})$ in toluene $\left(15 \mathrm{~mL}\right.$ ) under reflux (bath temp. $120^{\circ} \mathrm{C}$ ) for $36 \mathrm{~h}$ gave the mixed lactams 12d and 13d (total $200 \mathrm{mg}, 59^{\circ}$ )), ratio $56: 44$ by ${ }^{1} \mathrm{H}$ NMR spectroscopy.

Method B. Heating the ester-aldehyde 9 (95 $\mathrm{mg}, 0.40 \mathrm{mmol})$ and $(S)$-2-amino-1-propanol 11d $(45 \mathrm{mg}, 0.60 \mathrm{mmol})$ in xylene $(5 \mathrm{~mL})$ at $155^{\circ} \mathrm{C}$ (bath temp.) for $3 \mathrm{~d}$ followed by removal of the solvent in vacuo gave a mixture of isomeric lactams (ratio $85: 15$ ). Chromatography (EtOAc-hexane, $15: 85$ ) gave the title compound 12d (76 mg, 72\%) as a colourless oil; $[\alpha]_{\mathrm{D}}^{29}-143 \pm 7$ ( c 3.6, $\left.\mathrm{CHCl}_{3}\right)$; $v_{\max } / \mathrm{cm}^{-1} 3065,2975,2887,1638,1451,1410,1217,940,912,748$, $730 ; \delta_{\mathrm{C}}\left(100 \mathrm{MHz}, \mathrm{CDCl}_{3}\right) 18.3(\mathrm{Me}), 52.7$ (7-C), 72.8 (6-C), 85.7 (4b-C), 121.7, 128.1 (two), 128.9, 129.4, 129.9, 130.0 and 131.1 $(\mathrm{ArCH}), 134.9,136.17,136.20$ and 138.5 (quaternary $\mathrm{ArC}$ ), 163.7 (8-C); $m / z 266\left([\mathrm{M}+\mathrm{H}]^{+}, 100 \%\right)$ (Found: $\mathrm{M}+\mathrm{H}, 266.1165$; $\mathrm{C}_{17} \mathrm{H}_{16} \mathrm{O}_{2} \mathrm{~N}$ requires 266.1176); $R_{\mathrm{f}} 0.20$ (EtOAc-hexane, $3: 7$ ). Further elution of the column yielded a mixed fraction $(17 \mathrm{mg}$, $16 \%)$ and a fraction enriched in the minor isomer $13 \mathrm{~d}(10 \mathrm{mg}$, $10 \%$, ca. $80 \%$ d.e. by ${ }^{1} \mathrm{H}$ NMR spectroscopy) as a colourless oil; $v_{\max } / \mathrm{cm}^{-1} 2964,2923,2912,2841,1632,1463,1407,1094,741 ; \delta_{\mathrm{C}}$ (75 MHz, $\mathrm{CDCl}_{3}$ ) 19.1 (Me), 52.9 (7-C), 73.7 (6-C), 85.7 (4b-C), 121.7, 128.2, 128.3, 128.9, 129.7, 129.8, 130.2 and 131.5 ( $\mathrm{ArCH})$, 134.1, 135.9, 137.1 and 139.8 (quaternary $\operatorname{ArC}$ ), $163.6(8-\mathrm{C}) ; \mathrm{m} / \mathrm{z}$ $266\left([\mathrm{M}+\mathrm{H}]^{+}, 100 \%\right)$ (Found: $\mathrm{M}+\mathrm{H}, 266.1181 ; \mathrm{C}_{17} \mathrm{H}_{16} \mathrm{O}_{2} \mathrm{~N}$ requires 266.1176$) ; R_{\mathrm{f}} 0.14$ (EtOAc-hexane, $\left.3: 7\right)$. 
(a $S, 4 \mathrm{~b} R, 7 S)$-7-Phenylmethoxymethyl-6,7-dihydrodibenz$[c, e]$ oxazolo[3,2-a]azepin-9(4bH)-one $12 \mathrm{e}$ and $(\mathrm{a} R, 4 \mathrm{bS}, 7 S)-7-$ phenylmethoxymethyl-6,7-dihydrodibenz $[c, e]$ oxazolo[3,2-a]azepin-9 $(4 \mathrm{~b} H)$-one $13 \mathrm{e}$

Method A. Heating the acid-aldehyde 7 (100 mg, $0.44 \mathrm{mmol})$ and $(R)$-2-amino-3-benzyloxy-1-propanol 11e $(120 \mathrm{mg}$, $0.66 \mathrm{mmol})$ in toluene $(15 \mathrm{~mL})$ under reflux (bath temp. $120^{\circ} \mathrm{C}$ ) for $36 \mathrm{~h}$ gave the mixed lactams $\mathbf{1 2} \mathrm{e}$ and $\mathbf{1 3 e}$ (total $100 \mathrm{mg}$, $61 \%$ ), ratio $1: 1$ by ${ }^{1} \mathrm{H}$ NMR spectroscopy.

Method B. Heating the ester-aldehyde 9 (79 $\mathrm{mg}, 0.33 \mathrm{mmol})$ and $(R)$-2-amino-3-benzyloxy-1-propanol 11e (89 mg, $0.49 \mathrm{mmol})$ in xylene $(5 \mathrm{~mL})$ at $155^{\circ} \mathrm{C}$ (bath temp.) for $3 \mathrm{~d}$ followed by removal of the solvent in vacuo gave a mixture of isomeric lactams (ratio 87 : 13). Chromatography (EtOAc-hexane, $15: 85$ ) gave the title compound 12e (90 mg, 74\%) as a colourless gum; $[\alpha]_{\mathrm{D}}^{29}-96 \pm$ 7 (c 4.1, $\left.\mathrm{CHCl}_{3}\right) ; v_{\max } / \mathrm{cm}^{-1} 3063,2950,2885,1640,1451,1409$, 1214, 1097, 920, 748, 737; $\delta_{\mathrm{C}}\left(100 \mathrm{MHz} \mathrm{CDCl}_{3}\right) 56.0(7-\mathrm{C}), 67.7$ $\left(\mathrm{CH}_{2}\right), 69.2\left(\mathrm{CH}_{2}\right), 73.5\left(\mathrm{CH}_{2}\right), 86.0$ (4b-C), 121.9, 127.8 (three), $128.1,128.2,128.5$ (two), 129.0, 129.4, 130.0 and $130.1(\mathrm{ArCH})$, 134.5, 136.2 (two), 138.1 and 138.4 (quaternary $\mathrm{ArC}$ ), 164.2 (8C); $m / z 394\left([\mathrm{M}+\mathrm{Na}]^{+}, 100 \%\right), 372\left([\mathrm{M}+\mathrm{H}]^{+}, 47\right)$ (Found: $\mathrm{M}+$ $\mathrm{Na}, 394.1421 ; \mathrm{C}_{24} \mathrm{H}_{21} \mathrm{O}_{3} \mathrm{NNa}$ requires 394.1414); $R_{\mathrm{f}} 0.29$ (EtOAchexane, $3: 7)$. Further elution of the column yielded a mixed fraction $(28 \mathrm{mg}, 23 \%$, ratio $12 \mathrm{e}: 13 \mathrm{e} 1: 1.6) R_{\mathrm{f}} 0.29+0.21$ (EtOAchexane, $3: 7)$.

(aS,4bR,7S)-7-tert-Butyl-6,7-dihydrodibenz [c,e]oxazolo[3,2a]azepin-9 $(4 \mathrm{~b} H)$-one $12 \mathrm{f}$ and $(\mathrm{a} R, 4 \mathrm{~b} S, 7 S)$-7-tert-Butyl-6,7dihydrodibenz $[c, e]$ oxazolo[3,2-a]azepin-9(4bH)-one $13 \mathrm{f}$

Method A. Heating the acid-aldehyde 7 (280 mg, $1.24 \mathrm{mmol})$ and $(S)$-tert-leucinol $11 \mathrm{f}(216 \mathrm{mg}, 1.84 \mathrm{mmol})$ in toluene $(15 \mathrm{~mL})$ under reflux (bath temp. $120^{\circ} \mathrm{C}$ ) for $36 \mathrm{~h}$ gave the mixed lactams 12f and 13f (total $210 \mathrm{mg}, 55 \%$ ), ratio $64: 36$ by ${ }^{1} \mathrm{H}$ NMR spectroscopy, as a colourless gum; $v_{\max } / \mathrm{cm}^{-1} 3067,2966,2873$, $2244,1650,1452,1394,1219,1153,1083,912,741 ; \mathrm{m} / \mathrm{z} 308([\mathrm{M}+$ $\left.\mathrm{H}]^{+}, 100 \%\right)$.

Method B. Heating the ester-aldehyde 9 (230 mg, $0.96 \mathrm{mmol})$ and the amino alcohol $11 \mathrm{f}(168 \mathrm{mg}, 1.43 \mathrm{mmol})$ in xylene $(15 \mathrm{~mL})$ at $155{ }^{\circ} \mathrm{C}$ (bath temp.) for $3 \mathrm{~d}$ gave no lactams by ${ }^{1} \mathrm{H}$ NMR spectroscopy.

\section{Molecular mechanics calculations (Table 4, Fig. 1 and Fig. 2)}

Minimised steric energy (MSE) values for the lactams 12, 13 (Table 4), and 16-21 (Fig. 1) were calculated on a PC running Linux (Fedora Core 3) with MacroModel v. 8.0 (Maestro v. 5.0 interface) using the MM3 force field and Monte Carlo conformational search (csearch) method (1000 iterations). The standard minimisation parameters were: no solvent; PRCG method; convergence on gradient; max. number of iterations 3000; convergence threshold 0.0200 . The procedure returned multiple repeats of the same global MSE in each case. The difference, $\Delta G$, for each pair of structures $\mathbf{1 2}$ and $\mathbf{1 3}$ was converted into the equilibrium populations indicated in Table 4 using the equation $\Delta G=-R T \ln K$ (where $R=8.31451 \mathrm{~J} \mathrm{~K}^{-1} \mathrm{~mol}^{-1}$ ). The dihedral driving (drive) plots shown in Fig. 2 were acquired by locating the energy-minimised structure for $\mathbf{1 6}$ using csearch as described above, and then disconnecting the oxazolidine ring at $\mathrm{C}(4 \mathrm{~b})$. The identities of $\mathrm{H}(4 \mathrm{~b})$ and $\mathrm{O}(5)$ were exchanged and the oxazolidine ring was then reconnected. A constraint (force constant 100, range $\pm 10^{\circ}$ ) was imposed on the $(S)$-configured biaryl torsion angle $\left(42.5^{\circ}\right)$ and the structure was subjected to a new csearch operation. The torsional constraint was removed from the resulting structure, ent-17, whose steric energy was then minimised (mini) once more. MSE values for 18-21 were calculated similarly. The structures 16 and ent-17 were each subjected to a drive analysis of the dihedral angle $\mathrm{C}(1)-\mathrm{C}(13 \mathrm{~b})-\mathrm{C}(13 \mathrm{a})-\mathrm{C}(13)$ in the region of the respective minima (interval $0.1^{\circ}$ ), which provided the data for the plots in Fig. 2. The calculated MSE values $\left(\mathrm{kJ} \mathrm{mol}^{-1}\right)$ were: 16, 103.95; 17, $214.47 ; \mathbf{1 8}, 118.87$; 19, 118.28; 20, 27.67; 21, 55.44.

\section{Acid-induced equilibration of lactams (Table 5)}

Except for entry 1, all temperatures are those of oil baths and are approximate $\left( \pm 5^{\circ} \mathrm{C}\right)$.

Entry 1. A solution of the lactam 12a (11.2 mg, $0.038 \mathrm{mmol})$ and $p$-toluenesulfonic acid hydrate $(2.6 \mathrm{mg}, 0.014 \mathrm{mmol})$ in $\mathrm{CD}_{3} \mathrm{CN}(6 \mathrm{~mL})$ was heated at $55 \pm 2{ }^{\circ} \mathrm{C}$ (bath) for a total of $33 \mathrm{~d}$, during which time samples were periodically removed for analysis by ${ }^{1} \mathrm{H}$ NMR spectroscopy. The integrals for the respective $\mathrm{H}(4 \mathrm{~b})$ signals were used to monitor the change in the diastereoisomer ratio $[13 a] /[12 a]$. The data used to plot Fig. 3 are listed in Table 6.

Table 6 Data used to plot Fig. 3

\begin{tabular}{rc}
\hline 12a $(\%)$ & Time/h \\
\hline 100.0 & 0.0 \\
98.1 & 9.0 \\
96.8 & 15.0 \\
77.6 & 107.0 \\
65.2 & 184.5 \\
58.6 & 250.5 \\
46.4 & 419.5 \\
43.8 & 493.0 \\
40.2 & 611.0 \\
38.2 & 688.0 \\
36.7 & 758.5 \\
36.0 & 805.5 \\
\hline
\end{tabular}

For the equilibration of $\mathbf{A}$ and $\mathbf{B}$ via first-order processes, the change in concentration of $\mathbf{A}$ is related to the respective forward and reverse rate constants $k_{1}$ and $k_{-1}$ using the expression

$$
\frac{\mathrm{d}[\mathbf{A}]}{\mathrm{d} t}=-k_{1}[\mathbf{A}]+k_{-1}[\mathbf{B}]
$$

and the equilibration process is represented by the integrated rate equation, eqn (2).

$$
[\mathbf{A}]_{t}=[\mathbf{A}]_{\infty}+\left([\mathbf{A}]_{0}-[\mathbf{A}]_{\infty}\right) e^{-\left(k_{1}+k_{-1}\right) t}
$$

The value of $k_{-1}$ corresponds to $k_{1} / K$, where $K$ is the value of $[\mathbf{B}] /[\mathbf{A}]$ at equilibrium.

Fig. 3 was plotted using the observed isomer ratios listed in Table 6 . The calculated exponential decay curve for [12a] was generated using eqn (2) with the variables $[\mathbf{1 2 a}]_{\infty},\left\{[\mathbf{1 2} \mathbf{a}]_{0}-[\mathbf{1 2} \mathbf{a}]_{\infty}\right\}$ and $\left(k_{1}+k_{-1}\right)$ optimised by minimising the sum of the $R^{2}$ values for each data point. The data yielded the following parameters (errors approximate, based on $\pm 2 \%$ accuracy in NMR integrals):

$$
k_{1}=7.3 \times 10^{-7} \mathrm{~s}^{-1}\left( \pm 0.3 \times 10^{-7}\right)
$$


$k_{-1}=3.7 \times 10^{-7} \mathrm{~s}^{-1}\left( \pm 0.3 \times 10^{-7}\right)$

$[\mathbf{A}]_{\infty}=34 \%( \pm 2 \%)$

$[\mathbf{A}]_{0}-[\mathbf{A}]_{\infty}=67 \%( \pm 2 \%)$

Entry 2. A solution of the lactam 12a $(8.2 \mathrm{mg}, 0.028 \mathrm{mmol})$ and $p$-toluenesulfonic acid hydrate $(2.0 \mathrm{mg}, 0.011 \mathrm{mmol})$ in toluene- $d_{8}$ $(0.6 \mathrm{~mL})$ was heated in a sealed tube at $140{ }^{\circ} \mathrm{C}$ for $3 \mathrm{~d}$, during which time the mixture was periodically analysed by ${ }^{1} \mathrm{H}$ NMR spectroscopy. The estimated equilibrium ratio 12a : 13a was 27 : 73.

Entry 3. A solution of the lactam 12a (11.2 mg, $0.038 \mathrm{mmol})$ in toluene- $d_{8}(0.6 \mathrm{~mL})$ was heated in a sealed tube at $140{ }^{\circ} \mathrm{C}$ for $7 \mathrm{~d}$, after which time the ${ }^{1} \mathrm{H}$ NMR spectrum indicated that 12a remained intact. No other products were evident.

Entry 4. A sample of the lactam 12a $(20 \mathrm{mg}, 0.07 \mathrm{mmol})$ in toluene- $d_{8}(0.5 \mathrm{~mL})$ in an NMR tube was treated with a solution of TFA in toluene- $d_{8}(6.7 \mathrm{M}, 0.1 \mathrm{~mL}, 0.67 \mathrm{mmol})$. The stoppered tube was sealed in a screw-capped thick-walled glass tube and heated at $100{ }^{\circ} \mathrm{C}$ for $7 \mathrm{~d}$. The equilibration, monitored by ${ }^{1} \mathrm{H}$ NMR spectroscopy, stabilised with an estimated $\mathbf{1 2 a}: 13 \mathbf{a}$ ratio of $29: 71$.

Entry 5. A sample of the lactam $\mathbf{1 2 b}(20 \mathrm{mg}, 0.06 \mathrm{mmol})$ in toluene- $d_{8}(0.5 \mathrm{~mL})$ in an NMR tube was treated with a solution of TFA in toluene- $d_{8}(6.7 \mathrm{M}, 0.1 \mathrm{~mL}, 0.67 \mathrm{mmol})$. The stoppered tube was sealed in a screw-capped thick-walled glass tube and heated at $100{ }^{\circ} \mathrm{C}$ for $7 \mathrm{~d}$. The equilibration, monitored by ${ }^{1} \mathrm{H}$ NMR spectroscopy, stabilised with an estimated $\mathbf{1 2 b}: \mathbf{1 3 b}$ ratio of $45: 55$.

Entry 6. A sample of the lactam $\mathbf{1 2 b}(50 \mathrm{mg})$ in xylene $(10 \mathrm{~mL})$ was sealed in a screw-capped thick-walled glass tube and heated at $150{ }^{\circ} \mathrm{C}$ for $2 \mathrm{~d}$. Evaporation of the solvent and analysis of the residue by ${ }^{1} \mathrm{H}$ NMR spectroscopy indicated that no equilibration had occurred.

Entry 7. A sample of the lactam 12c $(20 \mathrm{mg}, 0.06 \mathrm{mmol})$ in toluene- $d_{8}(0.5 \mathrm{~mL})$ in an NMR tube was treated with a solution of TFA in toluene- $d_{8}(6.7 \mathrm{M}, 0.1 \mathrm{~mL}, 0.67 \mathrm{mmol})$. The stoppered tube was sealed in a screw-capped thick-walled glass tube and heated at $100{ }^{\circ} \mathrm{C}$ for $7 \mathrm{~d}$. The equilibration, monitored by ${ }^{1} \mathrm{H}$ NMR spectroscopy, stabilised with an estimated $12 \mathrm{c}: 13 \mathrm{c}$ ratio of $36: 64$.

Entry 8. A sample of the lactam 12c $(20 \mathrm{mg}, 0.06 \mathrm{mmol})$ in formic acid $(4 \mathrm{~mL})$ was sealed in a screw-capped thick-walled glass tube and heated at $100{ }^{\circ} \mathrm{C}$ for $3 \mathrm{~d}$. Evaporation of the solvent and analysis of the residue by ${ }^{1} \mathrm{H}$ NMR spectroscopy gave an estimated $12 c: 13 c$ ratio of $43: 57$.

Entry 9. A mixture of the lactams $\mathbf{1 2 d}$ and 13d (ratio $c a$. 56 : $44 ; 20 \mathrm{mg}, 0.075 \mathrm{mmol})$ in toluene- $d_{8}(0.5 \mathrm{~mL})$ in an NMR tube was treated with a solution of TFA in toluene- $d_{8}(6.7 \mathrm{M}$, $0.1 \mathrm{~mL}, 0.67 \mathrm{mmol})$. The stoppered tube was sealed in a screwcapped thick-walled glass tube and heated at $100{ }^{\circ} \mathrm{C}$ for $7 \mathrm{~d}$. The equilibration, monitored by ${ }^{1} \mathrm{H}$ NMR spectroscopy, stabilised with an estimated $\mathbf{1 2 d}: \mathbf{1 3 d}$ ratio of $34: 66$.

Entry 10. A mixture of the lactams 12e and 13e (ratio $c a .50$ : 50 ; $50 \mathrm{mg}, 0.16 \mathrm{mmol})$ and TFA $(0.2 \mathrm{~mL}, 2.7 \mathrm{mmol})$ in xylene $(10 \mathrm{~mL})$ was sealed in a screw-capped thick-walled glass tube and heated at $150{ }^{\circ} \mathrm{C}$ for $3 \mathrm{~d}$. The equilibration, monitored by ${ }^{1} \mathrm{H}$ NMR spectroscopy, stabilised with an estimated $\mathbf{1 2 e}: \mathbf{1 3 e}$ ratio of $30: 70$.

Entry 11. A mixture of the lactams $\mathbf{1 2 f}$ and $\mathbf{1 3 f}$ (ratio $c a$. $64: 36 ; 20 \mathrm{mg}, 0.065 \mathrm{mmol})$ in toluene- $d_{8}(0.5 \mathrm{~mL})$ in an NMR tube was treated with a solution of TFA in toluene- $d_{8}(6.7 \mathrm{M}$, $0.1 \mathrm{~mL}, 0.67 \mathrm{mmol})$. The stoppered tube was sealed in a screwcapped thick-walled glass tube and heated at $100{ }^{\circ} \mathrm{C}$ for $7 \mathrm{~d}$. The equilibration, monitored by ${ }^{1} \mathrm{H}$ NMR spectroscopy, stabilised with an estimated $\mathbf{1 2 f}: \mathbf{1 3 f}$ ratio of $26: 74$.

\section{Acknowledgements}

We are grateful to the Association for International Cancer Research, the EPSRC and GlaxoSmithKline for their financial support of this work. We also thank Val Boote and Steve Kelly for assistance with MS and NMR measurements, and Drs Andrew Regan and Ian Watt for valuable discussions. We also wish to acknowledge the use of the EPSRC's Chemical Database Service at Daresbury. ${ }^{32}$

\section{References}

1 Reviews: (a) T. W. Wallace, Org. Biomol. Chem., 2006, 4, 3197-3210; (b) G. Bringmann, A. J. Price Mortimer, P. A. Keller, M. J. Gresser, J. Garner and M. Breuning, Angew. Chem., Int. Ed., 2005, 44, 5384-5427.

2 A. I. Meyers and J. J. Willemsen, Chem. Commun., 1997, 1573-1574 and references cited therein.

3 A. Brossi, J. Med. Chem., 1990, 33, 2311-2319. See also: U. Berg and H. Bladh, Helv. Chim. Acta, 1999, 82, 323-325.

4 A. Brossi, O. Boyé, A. Muzaffar, H. J. C. Yeh, V. Toome, B. Wegrzynski and C. George, FEBS Lett., 1990, 262, 5-7.

5 For examples, see: K. Mikami, K. Aikawa, Y. Yusa, J. J. Jodry and M. Yamanaka, Synlett, 2002, 1561-1578; A. Alexakis and C. Benhaim, Eur. J. Org. Chem., 2002, 3221-3236; T. Ooi, Y. Uematsu, M. Kameda and K. Maruoka, Angew. Chem., Int. Ed., 2002, 41, 1551-1554; B. Lygo, B. Allbutt and S. R. James, Tetrahedron Lett., 2003, 44, 5629-5632; K. Morioka, N. Tamagawa, K. Maeda and E. Yashima, Chem. Lett., 2006, 35, 110-111.

6 D. J. Edwards, R. G. Pritchard and T. W. Wallace, Acta Crystallogr., Sect. B: Struct. Sci., 2005, 61, 335-345.

7 Z. Zhang, H. Qian, J. Longmire and X. Zhang, J. Org. Chem., 2000, 65, 6223-6226.

8 D. Romo and A. I. Meyers, Tetrahedron, 1991, 47, 9503-9569; M. D. Groaning and A. I. Meyers, Tetrahedron, 2000, 56, 9843-9873.

9 D. J. Edwards, R. G. Pritchard and T. W. Wallace, Tetrahedron Lett., 2003, 44, 4665-4668.

10 Y. Kubo, T. Araki and K. Maruyama, Bull. Chem. Soc. Jpn., 1985, 58, 2863-2869.

11 L. Giraud, E. Lacôte and P. Renaud, Helv. Chim. Acta, 1997, 80, 2148 2156.

12 M. Penhoat, V. Levacher and G. Dupas, J. Org. Chem., 2003, 68, $9517-$ 9520.

13 M. Penhoat, S. Leleu, G. Dupas, C. Papamicaël, F. Marsais and V. Levacher, Tetrahedron Lett., 2005, 46, 8385-8389.

14 R. A. Labriola and A. Felitte, J. Org. Chem., 1943, 8, 536-539.

15 E. F. M. Stephenson, J. Chem. Soc., 1954, 2354-2357.

16 P. S. Bailey and R. E. Erickson, Org. Synth., 1973, coll. vol. 5, pp. 493-495.

17 K. Schlögl and R. Schölm, Monatsh. Chem., 1980, 111, 259-274.

18 K. Schlögl and R. Schölm, Liebigs Ann. Chem., 1980, 1877-1888.

19 A. J. Mancuso and D. Swern, Synthesis, 1981, 165-185.

20 H. Kalchhauser, K. Schlögl, W. Weissensteiner and A. Werner, J. Chem. Soc., Perkin Trans. 1, 1983, 1723-1729.

21 The rotation barrier in formamide has been estimated at $72 \mathrm{~kJ} \mathrm{~mol}^{-1}$ using ab initio methods. E. D. Glendening and J. A. Hrabal, J. Am. Chem. Soc., 1997, 119, 12940-12946. See also: X. Lopez, J. I. Mujika, G. M. Blackburn and M. Karplus, J. Phys. Chem. A, 2003, 107, 2304 2315. 
22 K. Higashiyama, H. Inoue and H. Takahashi, Tetrahedron Lett., 1992, 33, 235-238.

23 W. Ando, Y. Igarashi and L. Huang, Chem. Lett., 1987, 1361-1364. See also: D. Seebach and J. D. Aebi, Tetrahedron Lett., 1984, 25, 2545-2548.

24 M. Amat, N. Llor and J. Bosch, Tetrahedron Lett., 1994, 35, 22232226; M. Amat, J. Bosch, J. Hidalgo, M. Cantó, M. Pérez, N. Llor, E. Molins, C. Miravitlles, M. Orozco and J. Luque, J. Org. Chem., 2000, 65, 3074-3084.

25 P. Pigeon and B. Decroix, Tetrahedron Lett., 1997, 38, 1041-1042.

26 G. Hilt, F. Galbiati and K. Harms, Synthesis, 2006, 3575-3584.
27 M. Tichy, M. Budesinsky, J. Günterova, J. Zavada, J. Podlaha and I. Cisarova, Tetrahedron, 1999, 55, 7893-7906.

28 D. D. Perrin, W. L. F. Armarego and D. R. Perrin, Purification of Laboratory Chemicals, Pergamon, Oxford, 2nd edn, 1980.

29 W. C. Still, M. Kahn and A. Mitra, J. Org. Chem., 1978, 43, 2923-2925.

30 V. Brandmeier and M. Feigel, Tetrahedron, 1989, 45, 1365-1376.

31 J. M. Schomaker, B. R. Travis and B. Borhan, Org. Lett., 2003, 5, 3089-3092.

32 D. A. Fletcher, R. F. McMeeking and D. Parkin, J. Chem. Inf. Comput. Sci., 1996, 36, 746-749. 